\title{
A Rights-based Approach to Indigenous Sovereignty, Self- determination and Self-government in Canada
}

\section{Kathryn Reinders}

Department of Political Science, College of Social and Applied Human Sciences, University of Guelph, Guelph, ON Canada. Faculty supervisor: Dr. A. Paras. For correspondence, please email: kathryn@thereinders.ca

\section{Abstract}

The United Nations Declaration on the Rights of Indigenous People (UNDRIP) calls for the right to self-determination, as selfdetermination is a prerequisite for Indigenous people to recongnize their political, social, economic, and collective human rights. Canada has historically been unsupportive of UNDRIP as the federal government considers UNDRIP at odds with Canadian sovereignty and existing Canadian institutions. While the right to self-government is currently protected under section 35 of the Constitution Act, 1982, it is defined narrowly and falls short of allowing meaningful self-government for the majority of Indigenous people. This paper considers the conflicting nature of self-determination and self-government through considering the impact of Indigenous sovereignty on state sovereignity, an analysis of various approaches to selfgovernment in Canada, and the feasability of adopting a rights-based approach to self-government. This paper concludes that utilizing a human rights-based approach to self-government addresses the perceived conflicts at the state-level while providing for the creation of meaningful self-government arrangements. Self-government arrangements must be created by Indigenous communities for Indigenous communities in order to reflect the diverse needs of Indigenous people regardless of their territorial affiliation or formal Indian status.

Keywords: Canada, Human rights, Indigenous rights, Self-determination, Self-government, UNDRIP

\section{Introduction}

On February $14^{\text {th }} 2018$, Prime Minister Justin Trudeau told the House of Commons that his government would pursue a new Recognition and Implementation of Indigenous Rights Framework. This rights-based framework will aim to create significant mechanisms to allow for Indigenous selfgovernment (Tasker, 2018).

Currently, the right to Indigenous self-government is protected under section 35 of the Constitution Act, 1982. Section 35 states that the constitutional rights of the Aboriginal Peoples of Canada are:

Recognition of existing aboriginal and treaty rights:

35. (1) The existing aboriginal and treaty rights of the aboriginal peoples of Canada are hereby recognized and affirmed.

Definition of "aboriginal peoples of Canada":
(2) In this Act, "aboriginal peoples of Canada" includes the Indian, Inuit and Métis peoples of Canada.

Land claims agreements:

(3) For greater certainty, in subsection (1) "treaty rights" includes rights that now exist by way of land claims agreements or may be so acquired.

Aboriginal and treaty rights are guaranteed equally to both sexes:

(4) Notwithstanding any other provision of this Act, the aboriginal and treaty rights referred to in subsection (1) are guaranteed equally to male and female persons. (Department of Justice Canada, 2013) 
These Section 35 protections are understood as the right to self-government in matters directly relating to Indigenous communities and Indigenous cultures and do not include the right to the creation of sovereign Indigenous states within Canada. This existing framework recognizes that there are multiple approaches to self-government, including Indigenous government on Indigenous lands, specialized programming within broader public structures, and institutional arrangements. These approaches are implemented via new and existing treaties, legislation, contracts, and memoranda of understanding (Government of Canada, 2010).

While self-government at the community level is accepted as an inherent right of Indigenous peoples under the Constitution Act, 1982, the Charter definition of selfgovernment is narrow and falls short of allowing Indigenous peoples to recognize their political, social and economic, and collective rights. This article will consider the conflict between the rights of self-determination and self-governance outlined in the United Nations Declaration on the Rights of Indigenous Peoples on one hand, and protection of state sovereignty and state institutions on the other. Section one will consider the conflicting views of the nature of selfdetermination. Section two and three will consider the rightsbased argument for the recognition of the collective right to self-determination through self-government. Sections four and five consider current self-government frameworks and policy approaches in Canada. Section six considers the limitations to implementing self-governance in Canada, with section seven recommending that the government expand their recognition of self-government rights. The concluding paragraph will note the importance of using a human rightsbased approach, as a rights-based approach simultanelously addresses the potential conflicts between self-government and Canadian institutions while accomodating the diverse needs of Indigeous communities.

\section{The Conflicting Nature of Self- Determination as a Right}

Self-determination as a collective human right is one of the key rights laid out within the United Nations Declaration on the Rights of Indigenous Peoples (UNDRIP). Article three states that "Indigenous peoples have the right to selfdetermination. By that right they freely determine their political status and freely pursue their economic, social and cultural development" (United Nations, 2008, p. 4). However, self-determination means something inherently different to various groups of people. It often conjures up the idea of territorial succession on one hand and freedom for marginalized groups on the other.

Considered narrowly, self-determination can be viewed as being only applicable to states at a territorial level, where it applies to the collective right of all the citizens of a specific state to determine their international status (Quane, 1998). This territory-based consideration of self-determination does not allow for groups within a state to recognize their collective right to self-determination with respect to state governments and only allows for the entire state to determine their international status. A second consideration of selfdetermination surrounds state-sovereignty, and considers selfdetermination in light of de-colonization and state succession (Klabbers, 2006). While this approach acknowledges minority cultures within a state, it again only considers selfdetermination as related to establishing international status as a new state, separate from the colonial state. A third understanding of self-determination is procedural in nature, and deals with the right of minority groups within a nation to determine their futures through taking part in state-level decisions which impact them directly (Klabbers, 2006).

This third understanding of self-determination is most consistent with the aims of UNDRIP and Indigenous populations in Canada. UNDRIP does not provide any new rights, but it does seek to acknowledge the importance of selfdetermination in recognizing the civil, political, and collective rights of Indigenous peoples around the world. In setting out these individual and collective rights, UNDRIP recognizes the right of Indigenous peoples to remain socially and politically distinct (Lightfoot, 2016, p. 96). This effectively casts selfdetermination as the right of Indigenous peoples to selfgovern via their own institutions within the settler state, allowing for the pursuit of social and economic development according to their own collective needs (Favel \& Coates, 2016). This conception of self-determination supports the ability of Indigenous peoples to further protect and develop their rights to identity, language, education, health, and so on; it provides a framework for inclusion of Indigenous voices within settler state policy. Ultimately, UNDRIP provides an opportunity for Indigenous peoples to engage and negotiate for increased recognition of individual and collective rights at the national level, while providing an outlet to air their concerns if individual states will not come to the table (Champagne, 2013, p. 10).

Within Indigenous communities, self-determination is seen as an opportunity to address the minimum human rights standards required by Indigenous peoples to thrive and is achieved through self-government. The National Centre for First Nations Governance argues that UNDRIP and the right to self-determination allows First Nations people (and broader Indigenous peoples) to create strong governing capacity through leveraging Canadian systems along with engaging traditional cultures and customs (Missens, 2008, p. 2). Through balancing different styles of governance, Indigenous peoples can participate in meaningful nation-building, reaffirm existing human rights, and access treaty and territorial rights. The Assembly of First Nations (AFN) stresses that the collective right to self-determination and UNDRIP represent "the minimum human rights standards that are necessary for the dignity, survival and well-being of Indigenous peoples" (Assembly of First Nations, n.d.). AFN also stresses that the right to self-determination must apply to 
all levels of government within Canada in order to ensure meaningful recognition of a full suite of human rights for Indigenous peoples (Assembly of First Nations, 2017). The Native Women's Association of Canada adds to the conversation by focusing on the right of self-determination relative to recognizing Indigenous women's rights and reestablishing the reverence of women within Indigenous society (Native Women's Association of Canada, 2011).

At the national level, self-determination has been addressed both through the Truth and Reconciliation Commission (TRC), and the Federal Government as part of the response to the TRCs calls to action. Per the TRC, only through deploying UNDRIP and recognizing the right to selfdetermination can the Government of Canada integrate Indigenous people into our national system of governance while upholding our legal commitments to Indigenous and Treaty rights under Section 35(1) of the Constitution Act, 1982. The TRC views UNDRIP and the right to selfdetermination as the cornerstone for securing broader Indigenous rights through development of Indigenous systems of justice, health care, and education (Truth and Reconciliation Commission, 2015). By securing broader Indigenous rights within Canada, the Government can create a solid base for addressing the legacy of the residential school system, and begin the process of reconciliation. In this way, self-determination is both a part of and essential for reconciliation.

After a period of storied rejection, the Government of Canada has moved to embrace UNDRIP, with Prime Minister Justin Trudeau both acknowledging that Canada has not met its human rights obligations to Indigenous people and that UNDRIP provides the "the necessary principles, norms, and standards for reconciliation to flourish in twenty-first-century Canada" (Assembly of First Nations, n.d.). While there is concern that Canada is selectively endorsing UNDRIP as a normative and aspirational document (Lightfoot, 2016, p. 95), Trudeau's acknowledgement of UNDRIP as a useful framework to promote reconciliation is backed by the passage of private members Bill C-262 through the second reading. Bill C-262 legislates calls to action number 43 and 44 of the TRC, which ask the federal government to implement UNDRIP as a pathway towards reconciliation (call 43) through adoping a national action plan to meet the humanrights targets in UNDRIP (call 44) (White, 2018). In this way, the full adoption of UNDRIP through Bill C-262 is a vehicle of reconciliation between Indigenous people and the federal government, as well as enabling the meaningful recognition of the right to self-determination within the context of the Canadian state system.

\section{The Human Rights-based Approach to Self-Determination}

Indigenous peoples have had their human rights systematically violated by the assimilative and colonial policies of the Canadian state, most notably the Indian Act, 1876. The Indian Act reduced Indigenous peoples to state wards, with the main objective to ensure modernization and assimilation into Canadian mainstream culture (Coates, 2008). The Indian Act severely restricted the human rights of Indigenous peoples and allowed the federal government of Canada to have full control over Indigenous peoples, their affairs, their land, and ultimately their basic human rights (Coates, 2008; Lightfoot, 2016. p. 160). While active clauses have changed, this piece of federal legislation remains in effect today.

Although there have been substantial changes to the Indian Act since 1876 such as lifting voting restrictions, closing residential schools, and ending the enforcement of the permit system, it remains virtually un-amended with respect to self-determination and self-government. The Canadian government still holds significant control over the political structure, land claims agreements, and access to resource/economic development within both treaty and nonceded lands (Coates, 2008, p. 2-4). By maintaining the existing framework of governance over Indigenous peoples, we ensure that Indigenous populations in Canada continue to be micro-managed by the federal government, leading to continued cultural losses and disengagement from the political system and broader society. Only through amending the existing colonial structures can we ensure that Indigenous peoples can meaningfully access the full suite of human rights to which they are entitled.

Leveraging a human rights-based framework for the meaningful recognition of the collective right to selfdetermination allows Indigenous peoples to add legitimacy to negotiations with the state. In the case of Canada, there is little room for creative interpretations of existing laws which regulate Indigenous rights. Often arguing the right to selfdetermination could impede existing political bargains between Indigenous Nations and settler-states, challenge state sovereignty over natural resources, and undermine national unity through potential secessionist movements, settler countries such as Canada continue to push back against calls for further development of Indigenous rights (Gover, 2015. p. 347; Meyer, 2012). However, the human-rights-based approach openly acknowledges that self-determination is not an absolute human right and must be negotiated both with respect to international standards and customary law as well as within the context of state laws (McCorquodale, 1994). UNDRIP explicitly states that the right to self-determination is not the right to succession from the state; further, the human-rights approach acknowledges that Indigenous nations are not against the internal order of the Canadian state per-se, but are against giving up their indigeneity in exchange for full participation within the political and sociocultural fabric of the state (Assembly of First Nations, 2017).

This approach also acknowledges that values change over time. International law trends towards flexibility and allows for multiple understandings of a right, whereas state 
systems trend towards inflexibility (McCorquodale, 1994). Indigenous cultural values often sit apart from settler cultural values as they stress community governance and sharedownership and collaboration over the concept of individual citizen ownership and competition. Because of these conflicting value objectives, Indigenous institutions are often at odds with the priorities of settler government institutions (Assembly of First Nations, 2017). The right to selfdetermination expressed in UNDRIP provides the opportunity to seek balance between these competing views, as it allows for Indigenous groups to participate as a community in the meaningful determination of their political, economic, and social futures within the state government system. Essentially, the human-rights-based approach provides Indigenous peoples with the ability to claim membership in multiple political communities. Indigenous people can be selfdetermining as collective members of their individual Nation relative to the institutions of the Canadian state, while simultaneously enjoying their rights as citizens of Canada (Blackburn, 2009; McCorguodale, 1994).

\section{Towards rights: Self- determination through Self- government}

As stated above, the right to self-determination is not an absolute right, as an absolute right cannot be infringed upon by the state, and is not defined relative to state sovereigntyin short, absolute rights exist "no matter what" (Mavronicola, 2012. p.757). While the right to self-determination is protected under international customary law, it is understood that the right to self-determination is exercised within/under state sovereignty (Christie, 2007, p. 5). The fact that selfdetermination is not an absolute right does not diminish the importance of self-determination within Indigenous communities. Settler-governments tend to reject the community-based nature of Indigenous governments, undermining and/or absolving their legitimacy. This trend results in citizens, courts, and governments viewing inherent Indigenous rights through a narrow view which only extends to legal and political claims associated with traditional rights such as hunting, fishing, and treaty-supported land claims (Champagne, 2013). The Native Women's Association of Canada (2011) stresses that the right to self-determination can create more space for Indigenous voices within the narrow settler scope of Indigenous rights. Self-determination underpins the ability of Indigenous communities to pursue their economic, social, and cultural development and is directly related to land, resource, and territory management as well as to the future of their cultural traditions, systems of government, and all aspects of Indigenous life. As a collective right, self-determination provides the base upon which Indigenous communities recognize all other human-rights (Native Women's Association of Canada, 2011).
Indigenous groups within Canada point to the fact that historically each Nation was organized by government systems which were unique from that of early Canadian settlers, and just as importantly, unique from each other. Documented systems of Government included (but were not limited to): hereditary systems, confederacies, clan systems, and federations. Further, these unique governments existed within a Nation-to-Nation political system where each Nation had their own ties and alliances with other Nations (Native Women's Association of Canada, 2011). These systems were often characterised by the key role of spirituality, community and tradition as part of governance. As self-determination was eroded through the assimilative policies of the Canadian government, Indigenous societies became less co-operative, losing language, culture, and traditions. Indigenous activists argue that through this cultural genocide, Indigenous people have become marginalized both economically and politically, with women suffering the deepest losses as they were edged out of active community life (Native Women's Association, 2011).

Though self-determination, Indigenous groups hope to focus on rebuilding traditional systems of governance to increase citizen participation and foster effective Nation building. In this context Nation building focuses on the ability of Indigenous peoples to revitalize their Nations based on the development of institutions which prioritize self-rule through creating effective governance structures which are culturally supported and led by community members who are spirited with a strong strategic approach to decision-making (Seelau \& Seelau, 2014), Without self-determination supported through settler-government policy, Indigenous Nations will not be able to develop these effective governance structures and revitalize their Nations (Native Women's Association, 2011).

On a state-level, recognizing self-determination is best achieved through the recognition of Indigenous Nationhood via the creation of self-governance structures which exist in addition to and alongside the state-government. This approach was recommended by both the the Special Committee on Indian Self-Government, convened by the Government of Canada in 1983, as well as the Royal Commission on Aboriginal Peoples carried out by the Canadian federal government in 1991 (Missens, 2008). The importance of selfgovernance as a meaningful method of improving the day to day lives of Indigenous people cannot be understated.

The Assembly of First Nation's 2004 report Recognition and Implementation of First Nations Governments recognized that self-determination could be reached through a measure of limited sovereignty, termed "practical sovereignty" (Missens, 2008). Practical sovereignty calls for the meaningful delegation of governing powers from federal and provincial governments to Indigenous groups over matters which directly influence them. The argument for limited self-government arrangements and practical sovereignty relates to selfdetermination in that people with the ability to decide how best to govern their own lives will create opportunities for growth. 
Through those opportunities they will become strong and effective self-sustaining communities which benefit both themselves and the broader state (Missens, 2008, p. 4-6). The Harvard Project on American Indian Economic Development found that Nations who have the opportunity to self-govern out-perform other Nations which are governed by external forces in all categories from economic development to health care to natural resource management (The Harvard Project, 2010-2015). These real-world results illustrate the relationship between self-determination, self-government, and practical sovereignty.

\section{Existing Support for Self- governance in the Canadian political system}

Indigenous peoples have been actively using Canada's legal system to fight for greater access to self-government, resulting in over 100 First Nations communities moving from under the Indian Act to new self-government agreements with the federal government. These agreements result in greater control over reserve land, public policy, taxation capabilities, and Government-to-Government borrowing opportunities, as well as direct input into the relationship between Indigenous governments and local, provincial, and federal governments (Favel \& Coates, 2016, p. 10). Within the Canadian political system, existing Indigenous rights are recognized as inherent rights under section 35 of the Constitution Act, 1982. The federal government states that "recognition of the inherent right is based on the view that the Aboriginal peoples of Canada have the right to govern themselves in relation to matters that are internal to their communities, integral to their unique cultures, identities, traditions, languages and institutions, and with respect to their special relationship to their land and their resources." (Government of Canada, 2010). In this context an inherent right can be viewed as a right granted to Indigenous people as a refelction of the fact that Indigenous peoples existed as distinct self-governing socieities at point of European contact. However, Section 35(1) rights only recognize existing rights which were secured prior to 1982, and do not privide protection for collective rights such as self-determination and collective land ownership (Lightfoot, 2016. p. 160).

Several landmark cases since 1982 have helped define the scope of rights protected in the charter as they relate to self-government. Notably, R. v. Sparrow confirms that federal legislation which infringes upon an existing Indigenous right must be justified in infringing the relevant right, and must infringe in the least way possible (Dalton, 2006, p. 15); R. v. Van der Peet recognizes that Indigenous rights exist by virtue of the fact that Indigenous peoples were living in this land at the time of European contact, and that they had their own cultures, traditions, and societies (Morellato, 2008); and Delgamuuku v. British Columbia established that Indigenous title rights are not individual rights of Indigenous people, but are collective rights held in common by members of the title Nation and all decisions which relate to title land must be made by the entire title Nation (Dalton, 2006, p. 20). Taken together, these cases provide the legal basis for the right to self-government - notably that Indigenous peoples have rights under section 35(1) by virtue of the fact that they were autonomous peoples living on this continent at the time of European contact, they have collective territorial and decision-making rights to title land, and they hold sovereignty such that infringement of their existing rights must be justified.

Some Indigenous leaders and academics argue that the charter is used to limit the scope of Indigenous rights to only those cultural practices which existed at point-of-contact with Europeans (Borrows, 2017). Seeing the Charter as inherently colonial, there are concerns within Indigenous communities that the charter is not the right method to defend Indigenous rights as it was created without the input of Indigenous peoples and requires that conflicts be resolved through the court system, which undermines non-confrontational conflict resolution solutions favoured by Indigenous communities (Hogg \& Turpel, 1995). On the other side, groups like the Native Women's Association of Canada see the charter-based approach to Indigenous rights as a requirement to supporting a rights-based approach to Indigenous self-government (Hogg $\&$ Turpel, 1995). Seeing the entrenchment of Indigenous and treaty rights as a victory, some groups stress that inherent Indigenous rights are now seen as an accepted part of Canadian law, and the references to traditional cultures and pre-contact societies indicates that Canada is working towards full acceptance of the right to self-government (McNeil, 2007; Missens, 2008).

\section{Current Policy Approaches to Self- Government in Canada}

As of 2015 there are currently 22 self-government agreements which have been negotiated at the federal-level, with another 90 self-government negotiations in progress (Government of Canada, 2015). These agreements give some level of autonomy to Indigenous communities, often establishing self-government through granting Indigenous groups law-making powers in key policy areas such as education or family services. While federal level agreements tend to promote self-government through granting territorial autonomy, other arrangements for self-government include self-government through supporting collective identity, and self-government through creation of Indigenouslocal/provincial/federal intergovernmental partnerships. Selfgovernment through territorial autonomy occurs when the federal or provincial government delegate jurisdictional powers over various aspects of governance to an Indigenous group with a specific territory (Hogg \& Turpel, 1995). This method has the capacity to provide significant selfgovernment powers. Territorial autonomy allows for the 
extension of economic, social, and cultural development rights, as well as the right to create laws with respect to their territory and members (Kraljic \& Stolz, 2010). Typically, the powers delegated include a modified version of a full suite of municipal powers such as the provision of business licenses, planning, zoning, administration of local justice, environmental protection, and regulations of activities with the territory; however, some may find this scope too limiting as these regulations would only apply to members of the Nation who live within the defined territory, and not those who live elsewhere (Hogg \& Turpel, 1995).

As an example, the Nisga'a Final Agreement, reached in 2000 , removed the Nisga'a people from under the jurisdiction of The Indian Act, and provided Nisga'a Nation with Section 35 self-government rights over their land. Occupying 2,019 $\mathrm{km}^{2}$ of land in the Nass Valley, the Nisga'a Government is providing representation to Nisga'a people both living within their land, and surrounding areas. The Nisga'a Lisims Government has successfully provided their citizens with increasing recognition of their human rights though improving infrastructure, investing in additional telecommunications, creation of a community preventative program under Nisga'a Child \& Family Services, as well as enshrining significant accountability structures for elected representatives within their constitution (Nisga'a Lisims Government, n.d.).

While self-government derived from territorial autonomy may appear to be the gold standard for recognition of self-government rights, over fifty percent of those who selfidentify as Indigenous live outside of delineated territory (Dubois, 2011, p. 3). In this sense territorily defined selfgovernment creates a two-tier system where those who live in traditional communities have access to self-government and self-determination, while those who reside outside of their communities lack the ability to recognize self-government and self-determination of their own political status. By recasting self-government relative to Indigenous collective identity, those living outside of territorially defined communities can have access to meaningful self-government. This concept of self-government changes the locus of political authority from authority over territory to authority over Indigenous communities' relationships between people within their respective communities, their identity as Indigenous, and the land (in a non-territorial sense). This concept creates space for Indigenous people to access self-governance through creating institutions which speak to their relationships with each other, the land, and broader society, or through the creation of urban reserves (Dubois, 2011, p. 3; Hogg \& Turpel, 1995). As an example, membership in First Nations bands in Saskatchewan is not tied to reserve residence; in 2011 only 850 people of the 2387 citizens of Carry the Kettle First Nation resided on reserve (Dubois, 2011, p. 4), however they still identified as part of the Carry the Kettle Nation.

In Saskatchewan, new urban-reserves were created through Treaty Land Entitlement Framework Agreements (TLEFA). TLEFAs are provincial level agreements between the province of Saskatchewan, the federal government, and Indigeneous governments which allow for the addition or expansion of reserves in order to settle existing land debts. These urban-reserves are a first in Canada and remain unique to Saskatchewan. With nine urban-reserves existing in cities, TLEFA agreements create space for Indigenous people to recognize their right to purse economic self-sufficiency in urban environments outside of their band's main reserve territory (Dubois, 2011, p. 6). Other examples of selfgovernment through collective identity include organizations like Native Child and Family Services of Toronto, which provides family services though a unique model based on the culture and values of Indigenous peoples and the right to selfdetermination; and the Ontario Federation of Indigenous Friendship Centres, which provide culturally based social services and development, as well as undertaking significant policy research into a myriad of Indigenous social concerns.

A third form of self-government in Canada is exercised though the creation of Indigenous-governmental partnerships. These partnerships can exist at the local, provincial, or federal level and entail several different types of relationships. Land and resource management partnerships are typically federal or provincial in nature and provide self-governance through the recognition that the lands to be developed were occupied lands at the time of contact with European settlers (Morellato, 2008). These consultation arrangements typically involve some adaptation of resource management to cultural attachment to the land or resource. As an example, the BCHaida Protocol is a Nation-to-Nation protocol which acknowledges that the Haida have a unique view with respect to resource development in Haida Gwaii and limited sovereignty over the lands while British Columbia sees Haida Gwaii as crown land (Penikett, 2012, p. 8). The BC-Haida Protocol reconciled Indigenous and state sovereignty through creating a shared management council and providing an independent forestry industry for the Haida Nation. Haida Enterprises Corporation provides economic development to the Haida Nation, allowing citizens to access greater social, economic, and cultural rights (Indigenous Business and Investment Council, 2018).

However, shared governance protocols do not have to involve land or resource management. There are also a variety of shared governance agreements involving diverse policy areas such as tax-collection, social service provisions, and policing/health services between Indigenous Nations and federal or provincial governments as well as local partnerships for service provision on reserve lands (Hogg \& Turpel, 1995; Nelles \& Alcantara, 2013). As an example, hundreds of Indigenous-local intergovernmental agreements exist throughout British Columbia and Ontario. Typically, these agreements are service related (garbage collection, fire protection), but can also take the form of formal relationship agreements where local governments agree to work collaboratively with Indigenous Nations in surrounding areas. These agreements tend to focus on the decolonization of the 
relationship between Indigenous governments and local governments and can be some of the most powerful agreements for recognition of self-government as they acknowledge Indigenous sovereignty and capacity building (Nelles \& Alcantara, 2013).

\section{Limitations to the recognition of self-government and self- determination}

While the importance of self-determination and selfgovernance to the provision of Indigenous rights is undeniable, several limitations to the rights-based approach for the recognition of self-determination through selfgovernance need to be addressed. Because self-determination and self-government require that state governments (at all levels) accept both the sovereignty of Indigenous peoples and the fact that sovereignty means something different to each Indigenous Nation, implementing self-government becomes increasing complex. Frameworks for recognizing selfgovernment must be flexible enough to respond to a myriad of conditions which may or may not include fixed territorial sovereignty, the desire to create sovereign institutions for social service provisions, or the desire to leverage existing local, provincial, or federal services in support of selfdetermination.

However, flexibility is often hampered by the reality of working within the Canadian political system. Indigenous sovereignty is often at odds with crown sovereignty. There is a tendency to view Indigenous law in Canada as only pertaining to historic cultures and traditions, essentially eliminating any contemporary changes to Indigenous culture (Borrows, 2017). Essentially, the courts function on the assertation that the advent of Crown sovereignty removed the right of self-determination from Indigenous peoples, and that that self-determination, once removed, cannot be returned (Christie, 2007, p. 12). Further, if a conflict progresses to litigation, there is a tendency for the Crown to argue that Nations chose to give up their inherent rights through treaty negotiations, even though there have been widespread incidents of misinterpreted treaties (Christie, 2007). This forces Indigenous Nations to engage with the legal system to either prove that the treaty in question was not understood by the historic parties or that the parties misunderstood the implications of the treaty, or prove that the treaty itself does not explicitly state the absolute surrender of powers (Christie, 2007 , p. 10). By placing the onus on Indigenous Nations to prove their right to sovereignty over their own affairs within the state, Nations are unable to easily access their rights due to the massive economic and time costs of confronting the colonial state through court.

Outside of the sovereignty limitation, full selfgovernment is also relatively incompatible with Canadian law and the federal system. The Indian Act still covers most Nations, and is consistently a barrier to Nation building, through excluding membership and determining the governing structure on reserve. The existing legislation is nonspecific in nature. If Canada were to use the existing act to provide self-government rights, who would receive those benefits? "Real" status Indians? All people of Indigenous heritage? The overall structure of development on reserve along with the restrictions placed on additional federal funding programs make it difficult for communities with territorial authority to create culturally appropriate governance frameworks (Morellato, 2008). Further, our federal system was created with the understanding of shared powers between two levels of government: Federal and Provincial. While the Nisga'a Final Agreement has created a potential new level of governance, the rights provided to the Nisga'a government create self-rule outside of Provincial authority, not outside of Federal authority (Lightfoot, 2016, p. 177). This adds an additional layer of difficulty in negotiating self-government arrangements due to potential jurisdictional issues (Penikett, 2012, p. 4). Where does Indigenous jurisdiction fit in a system where all powers are Federal or Provincial per the Canadian constitution, without considering wholesale constitutional changes?

A third, but related concern involves the nature of selfgovernment agreements relative to treaties between tribal Nations, and recognition of Indigenous identity and selfgovernment at the international level. Prior to colonization, Indigenous Nations maintained their own Nation-to-Nation relations, with each community maintaining their own identity with unique ties to other Nations (Native Women's Association of Canada, 2011). In order to truly respect the full right of self-determination relative to pre-contact governance structures of Indigenous Nations, any self-government agreement needs to include the ability to negoitate freely with other Nations and the right to formally identify as a Nation. However, the right of Indigenous Nations to negotiate with other nations (both Indigenous and non-indigenous) as well as the right to formally identify as a nation are often supressed, as evidenced by the dismissal of Six Nation Haudenosaunee passports or the lack of meaningful Indigenous representation internationally (Gonnella, 2018; Marques, 2011. p. 385). Without providing an expanded view of self-government agreements which extend beyond a muncipal plus model of rights, self-government agreements may fall short of providing the full slate of rights laid out by UNDRIP.

\section{Policy Recommendations}

In the context of UNDRIP, self-determination refers to the ability of minority groups within a nation to determine their futures through taking part in state-level decisions which impact them directly (Klabbers, 2006). In the Canadian context, recognizing self-determination through selfgovernment will allow for the full integration of Indigenous peoples into federal and provincial governance structures, while securing broader Indigenous rights through developing Indigenous social services and territorial autonomy (Truth and 
Reconciliation Commission, 2015). In an ideal world, Canada would reform its political system to give Indigenous peoples meaningful self-government rights through creating an entire third order of government. Unfortunately, the extreme level of reform required to accommodate a third order of government renders that resolution improbable. While there is an understandable level of inherent distrust of settlerinstitutions due to the damaging nature of colonial attitudes and policy, any policy adopted must be reconcilable with Canada's existing institutions, as broad constitutional or legal changes are unlikely to occur (Alcantara \& Davidson, 2015, p. 557; Favel \& Coates, 2016).

Policies must reflect the knowledge that selfdetermination underpins the ability of Indigenous communities to pursue their economic, social, and cultural development. Self-determination is directly related to land, resource, and territory management as well as to the future of their cultural traditions, systems of government, and all aspects of Indigenous life. As a collective right, selfdetermination provides the base upon which Indigenous communities recognize all other human rights (Native Women's Association of Canada, 2011). From this perspective, any policy framework looking to achieve meaningful self-government must be based at the communitylevel and driven by Indigenous people. A community-based process allows community members to act according to their needs and within the context of traditional structures if they so choose (Imai, 2008).

While each Indigenous group will have different needs, self-government policies need to be able allow for the recognition of basic human rights through providing Indigenous control over community membership, family and children's services, health, education, property rights, political rights, language, culture, and land/resource management (Alcantara \& Davidson, 2015. p. 554). Further, policies need to reflect the idea that there is no best "one-size-fits all" practice since groups of Indigenous people differ in broad ways - coming from cultural backgrounds unique from one another, living all over the country both on and off reserve, and holding either formal Indian status or self-identified status.

For this reason, a robust program which allows for strong, self-governing Indigenous Nations with territorial autonomy, along with national, Indigenous-led social services that respect the culture and collective identity of Indigenous peoples will provide the best environment to implement a rights-based approach to self-government.

By interpreting the existing Aboriginal and treaty rights protected in section 35(1) of the Constitution Act, 1982 as dynamic rights which grow and change along with communites, instead of strictly historic rights like hunting, fishing, and treaty-supported land claims (Borrows, 2017; Champagne, 2013) combined with referencing R v. Van der Peet, which recognizes that Indigenous peoples were selfgoverning, autonomous Nations at point of contact (Morellato,
2008, p. 8-9), existing Canadian laws and precedents could allow for an expanded concept of Aboriginal rights. This expanded understanding would allow for the creation of a national, collaborative, and community-based Indigenous social services framework. By establishing a network of social services which exist outside of the confines of physical territory, all individuals who self-identify as Indigenous can secure services within their own communities, provided by their own people if they so choose, effectively addressing issues with colonial social services and the potential for twotier access to self-government based on territorial affiliation or lack thereof.

With a strong system of social institutions which recognize the collective identity of Indigenous peoples established, individual Nations would then be free to pursue self-government arrangements with the crown. In this regard, the creation of a strong and independent government similar to the Nisga'a Lisms Government would be the gold standard, as this form of governance allows Indigenous populations to remove Indian Act administrative practices, and focus on Nation building with respect to their own unique cultures and traditions. This model exists somewhere between the minimunicipality model where Indigenous governments are delegated some powers but are still directly under provincial jurisdiction (Abele \& Prince, 2006); and a provincial model, where Indigenous Nations would exist at the same level as Federal and Provincial governments. By securing legal treaties along the lines of the Nisga'a Nation, self-government rights of individual Nations would be Federally acknowledged and when combined with the non-territorial provision of social service delivery, Indigenous peoples within Canada could achieve self-determination at a level consistent with the implementation of UNDRIP.

\section{Conclusion}

While the right to self-determination can conflict with state sovereignty, self-determination as laid out by UNDRIP is focused on securing the social, political, and economic rights of Indigenous people through a practical sovereignty which, while limited, allows Indigenous people meaningful control over state-level decisions which directly impact their Nations - not through territorial succession from the state. A human-rights based approach to self-determination respects that Indigenous peoples existed as distinct peoples with distinct cultures and distinct systems of governance at the time of European contact, and affirms that Indigenous communites have diverse values systems which are distinct from the values systems of settler society.

These competing values systems have historically resulted in colonial and assimilative state-level administration processes which have lead to economic and political marginalization and alienation. This legacy leads many communities to distrust settler institutions and question the settler-state's ability to resolve the legacy of colonialsim and promote self-determination and self-government. However, 
the Constitution Act, 1982 section 35(1) along with relevant case law can provide for self-government arrangements, provided we expand the way we read into the constitution and move past the idea that Indigenous rights are frozen in time at point of European contact. Through expanding the breadth of constitutionally protected Indigeouns rights to reflect the dynamic requirements of Indigenous populations, it is possible to restore the balance between competing value systems of Indigenous people and the settler-state by creating a broad system of self-government which meets the varying needs of Indigenous peoples within Canada.

Any policy framework for recognition of selfgovernance must be created by and implemented by Indigenous communities for Indigenous communities. While there is no one-size-fits-all best practice, the creation of a national network of community based, Indigenous led social service organizations combined with Nisga'a style modern treaties for territorially affiliated communities could provide meaningful self-government for all Indigenous peoples regardless of whether they have a territorial affiliation or hold formal Indian status. Through self-government, Indigenous communties would be able to form strong communities and fully recognize the full suite of human rights called for within UNDRIP.

\section{Acknowledgements}

I would like to acknowledge Professor Andrea Paras for her assistance, feedback, and support during the process of writing this paper.

\section{References}

Abele, F., \& Prince, M. J. (2006). Four pathways to aboriginal self-government in Canada. American Review of Canadian Studies, 36(4), 568-595. doi:10.1080/02722010609481408

Alcantara, C., \& Davidson, A. (2015). Negotiating aboriginal self-government agreements in Canada: An analysis of the Inuvialuit experience. Canadian Journal of Political Science, $\quad 48(3), \quad 553-575$. doi: $10.1017 / \mathrm{S} 0008423915000402$

Assembly of First Nations. (n.d.). Implementing the United Nations Declaration. http://www.afn.ca/policysectors/implementing-the-undeclaration/

Assembly of First Nations (2017, November). Implementing the United Nations Declaration on the Rights of Indigenous Peoples. http://www.afn.ca/wpcontent/uploads/2018/02/17-11-27-Implementing-theUN-Declaration-EN.pdf

Blackburn, C. (2009). Differentiating Indigenous Citizenship: Seeking Multiplicity in Rights, Identity, and Sovereignty in Canada. American Ethnologist, 36(1), 66-78. http://www.jstor.org.subzero.lib.uoguelph.ca/stable/2766 7529
Borrows, J. (2017). Challenging Historical Frameworks: Aboriginal Rights, The Trickster, and Originalism. The Canadian Historical Review. 98(1). Doi: 10.3138/chr.98.1.Borrows

Coates, K. (2008). The Indian Act and the Future of Aboriginal Governance in Canada. Research Paper for the National Centre for First Nations Governance. http://fngovernance.org/ncfng_research/coates.pdf

Champagne, D. (2013). UNDRIP (United Nations Declaration on the Rights of Indigenous Peoples): Human, Civil, and Indigenous Rights. Wicazo Sa Review, 28(1), 9-22. doi:10.5749/wicazosareview.28.1.0009

Christie, G. (2007). Aboriginal Nationhood and the Inherent Right to Self-Government. Research Paper for the National Centre for First Nations Governance. http://fngovernance.org/ncfng_research/gordon_christie. $\underline{\mathrm{pdf}}$

Dalton, J. E. (2006). Aboriginal Self-Determination in Canada: Protections Afforded by the Judiciary and Government. Canadian Journal of Law and Society, 21(1), 11-37. https://muse-jhuedu.subzero.lib.uoguelph.ca/article/203549/pdf

Department of Justice Canada. (2013). A Consolidation of THE CONSTITUTION ACTS 1867 - 1982. Publishing and Depository Services Public Works and Government Services Canada. https:/lawslois.justice.gc.ca/PDF/CONST_E.pdf

Dubois, J. (2011). Beyond Territory: Revisiting the Normative Justification of Self-Government in Theory and Practice. The International Indigenous Policy Journal, 2(2). http://ir.lib.uwo.ca/iipj/vol2/iss2/1

Favel, B \& Coates, K. (May). Understanding UNDRIP: Choosing action on priorities over sweeping claims about the United Nations Declaration on the Rights of Indigenous Peoples. MacDonald-Laurier Institute. https://www.macdonaldlaurier.ca/files/pdf/MLI-10UNDRIPCoates-Flavel05-16-WebReadyV4.pdf

Gonnella, M. (2018). If you are not at the table, then you are probably on the menu: Indigenous peoples' participatory status at the united nations. Suffolk Transnational Law Review 41(1), 145-172.

Government of Canada. (2010). The Government of Canada's Approach to Implementation of the Inherent Right and the Negotiation of Aboriginal Self-Government. http://www.aadncaandc.gc.ca/eng/1100100031843/1100100031844\#inhrs $\mathrm{g}$

Government of Canada. (2015). Fact Sheet: Aboriginal SelfGovernment. https://www.aadncaandc.gc.ca/eng/1100100016293/1100100016294 
Gover, K. (2015). Settler-State political theory, 'CANZUS' and the UN declaration on the rights of indigenous peoples. European Journal of International Law, 26(2), 345-373. doi:10.1093/ejil/chv019

Hogg, P, \& Turpel, M.E. (1995). Implementing Aboriginal Self-Government: Constitutional and Jurisdictional Issues. Canadian Bar Review, 74(2): 187-224. http://digitalcommons.osgoode.yorku.ca/cgi/viewcontent .cgi? article $=1669 \&$ context $=$ scholarly_works

The Harvard Project. (2010 - 2015). What Works, Where, and Why? https://hpaied.org/about

Imai, S. (2008). Indigenous Self-Determination and the State. Comparative Research in Law \& Political Economy. Research Paper No. 25. http://digitalcommons.osgoode.yorku.ca/clpe/196

Indigenous Business and Investment Council. (2018). Haida First Nation. https://www.bcibic.ca/successstories/haida-first-nation/

Kraljic, S, \& Stolz, A. (2010). Indigenous Peoples: From Unrighteousness to the Right to Self-Government. Lex localis - Revija za lokalno samoupravo 8(1): 35-63.

Lightfoot, S. (2016). Global indigenous politics : a subtle revolution.

http://ebookcentral.proquest.com/lib/uoguelph/detail.acti on? docID $=4530723$

Marques, N. (2011). Divided we stand: The haudenosaunee, their passport and legal implications of their recognition in canada and the united states. San Diego International Law Journal 13(1), 383-426.

Mavronicola, N. (2012). Deciphering Absoluteness in the Context of Article 3 of the European Convention on Human Rights. Human Rights Law Review [1461-7781], Vol 12(4): 723-758

McCorquodale, R. (1994). Self-Determination: A Human Rights Approach. The International and Comparative Law Quarterly,43(4), 857-885. Retrieved from http://www.jstor.org.subzero.lib.uoguelph.ca/stable/7610 04

McNeil, K. (2007). The Jurisdiction of Inherent Right Aboriginal Governments. Research Paper for the National Centre for First Nations Governance. http://fngovernance.org/ncfng_research/kent_moneil.pdf

Meyer, William H. (2012). "Indigenous Rights, Global Governance, and State Sovereignty." Human Rights Review. 13: 327-347.

Missens, R. (2008). Sovereignty, Good Governance and First Nations Human Resources: Capacity Challenges. Research Paper for the National Centre for First Nations Governance. http://fngovernance.org/ncfng_research/richard_missens. pdf

Morellato, M. (2008). The Crown's Constitutional Duty to Consult and Accommodate Aboriginal and Treaty Rights. Research Paper for the National Centre for First Nations Governance.

http://fngovernance.org/ncfng_research/maria_marletto. pdf

Native Women's Association of Canada. (2011). NWAC Reclaiming Our Nations Initiative: Nation-Building and Re-Building - Gathering Women's Wisdom Awareness and Engagement - Native Women's Association of Canada Staff Final Report. https://www.nwac.ca/wpcontent/uploads/2015/05/2011_NWAC_Reclaiming_Ou r_Nations_Initiative_Report.pdf

Nelles, J \& Alcantara, C. (2013). Explaining the Emergence of Indigenous-Local Intergovernmental Relations in Settler Societies: A Theoretical Framework. Urban Affairs Review. DOI: 10.1177/1078087413501638

Nisga'a Lisims Government. Accomplishments and Benefits of Nisga'a Treaty. http://www.nisgaanation.ca/aboutaccomplishments-and-benefits-nisgaa-treaty

Penikett, T. (2012). Six definitions of aboriginal selfgovernment and the unique Haida model. http://www.actioncanada.ca/wpcontent/uploads/2014/04/Haida-Gwaii-Governance-ENOct-2012.pdf

Quane, H. (1998). The United Nations and the Evolving Right to Self-Determination. The International and Comparative Law Quarterly, 47(3), 537-572. Retrieved from

http://www.jstor.org.subzero.lib.uoguelph.ca/stable/

Seelau, L., \& Seelau, R. (2014). Making Indigenous SelfDetermination Work: What the Nation Building Priciples and Three Case Studies From Chile Teach Us About Implementing Indigenous Human Rights. American Indian Law Review, 39(1), 137-199. Retrieved from http://www.jstor.org.subzero.lib.uoguelph.ca/stable/2436 7640

Tasker, J.P. (2018). Trudeau promises new legal framework for Indigenous people. CBC News: http://www.cbc.ca/news/politics/trudeau-speechIndigenous-rights-1.4534679

The Truth and Reconciliation Commission of Canada. (2015). Honouring the Truth, Reconciling for the Future Summary of the Final Report of the Truth and Reconciliation Commission of Canada. http://www.trc.ca/websites/trcinstitution/File/2015/Findi ngs/Exec_Summary_2015_05_31_web_o.pdf 
United Nations (2008). United Nations Declaration on the Rights of Indigenous Peoples. http://www.un.org/esa/socdev/unpfii/documents/DRIPS _en.pdf

White, D. (2018). Indigenous rights are nothing to fear. Times

Colonist: http://www.timescolonist.com/opinion/op-ed/commentIndigenous-rights-are-nothing-to-fear-1.23163 